\title{
IKLAN LAYANAN MASYARAKAT PEDULI SAMPAH
}

\author{
Juli Atika ${ }^{1}$, Rosta Minawati ${ }^{2}$, Agung EkoBudi Waspada ${ }^{3}$ \\ ${ }^{1,2}$ Program Studi Pascasarjana Institut Seni Indonesia Padang Panjang \\ ${ }^{3}$ Program Studi Desain Komunikasi Visual, Fakultas Seni Rupa dan Desain, \\ Istitut Teknologi Bandung \\ 1] Juliatika4@gmail.com, ${ }^{2}$ Rostaminawati@yahoo.com \\ 3agungebw83@yahoo.com
}

\begin{abstract}
ABSTRAK
Iklan layanan Masyarakat adalahiklan yang menyajikan pesan-pesan sosial yang bertujuan untuk membangkitkan kepedulian masyarakat terhadap sejumlah masalah yang harus mereka hadapi, yakni kondisi yang bisa mengancam keselarasan dan kehidupan umum.iklan layanan masyarakatbertema peduli sampah kini telah banyak dibuat dan ditayangkan di televisi atau pada jaringan internet. Iklan Layanan masyarakat ini juga mempunyai alur cerita yang berbeda-beda sesuai dengan tema dan sering yang dibuat dan digunakan, tetapi semuanya memiliki tujuan yang sama yaitu untuk menyampaikan pesan kepada masyarakat. Oleh karena itu penulis tertarik untuk membuat Iklan layanan Masyarakat Bertema peduli sampah dengan unsur pembuatan media seperti baliho, poster dan baju, Jadi dimanapun kebersihan tetap terjaga agar lingkungan tetap bersih dan sehat, maka penulis membuat sebuah iklan layanan masyarakat tersebut.
\end{abstract}

Kata Kunci :Iklan Layanan Masyarakat, Media, Peduli sampah.

\begin{abstract}
ABCTRACT
Public service ads are ads that present social messages aimed at generating public awareness of the issues they face, conditions that can threaten harmony and public life. public service ads with garbage-themed themes are now being created and broadcasted on television or on the internet. These public service announcements also have different storylines according to the theme and are often created and used, but all have the same goal of communicating the message to the public. Therefore, the authors are interested to create a Public-themed Service Concerned about waste with elements of making media such as billboards, posters and clothes, So wherever cleanliness is maintained to keep the environment clean and healthy, the authors make a public service ads.
\end{abstract}

Keywords: Public Service Ads, Media, Cares for garbage.

\section{PENDAHULUAN}

Kota Medan menjadi kota dengan perkembangan yang sangat pesat dan dikarenakan perkembangannya itu maka semakin kompleks juga permasalahan yang terjadi di dalamnya. Salah satunya masalah peduli sampah di lingkungan dikarenakan semangkin kurang kesadaran masyarakat akan hal sampah, sehingga sampah di kota medan semakin bertambah banyak.Selain itu kesadaran dari masyarakat di kota medan untuk membuang sampah masih sangat rendah dan dinilai juga masih sangat kurang efisien, dikarenakan tidak adanya kesadaran dari diri sendiri. Di samping itu juga penyedia tempat sampah masih dinilai kurang mencukupi. 
Dengan riset ini, peneliti dapat mengetahui apa saja kekurangan dari masyarakat kota Medan tentang peduli sampah dengan adanya iklan layanan masyarakat ini masyarakat kota medan semakin kuat untuk perduli terhadap sampah disekitarnya serta masyarakat kota Medan.

\subsection{Iklan Layanan Masyarakat}

Iklan Layanan Masyarakat adalah suatu media promosi untuk mendapatkan daya tarik masyarakat terhadap iklan yang dipromosikan dan sebagai media pelayanan serta organisasi sosial untuk dapat dikenal sebagai pelayanan masyarakat luas, sehingga Iklan Layanan Masyarakat ini diterbitkan serta menjadi sebagai pelayanan masyarakat dan sebuah pengumuman yang tidak mengambil keuntungan dan mempromosikan program-program, kegiatan-kegiatan, atau pelayanan-pelayanan dari pemerintah pusat/lokal, atau dari organisasi sosial, dan pengumuman-pengumuman lain yang dikenal sebagai pelayanan masyarakat [1].

Melaui Iklan Layanan Masyarakat ini masyarakat kota Medan dapat diajak berkomunikasi yang berguna untuk memikirkan sesuatu yang bersifat memunculkan kesadaran masyarakat itu sendiri serta dapat memunculkan kesadaran baru yang bersumber individual maupun kelompok [1].

Sampah adalah suatu bahan yang terbuang di lingkungan atau dibuang dari sumber hasil aktivitas masyarakat maupun proses alam yang belum memiliki nilai ekonomis serta sampah tersebut memiliki banyak dampak terutama penyakit serta bencana alam untuk dilingkungan sekitar yang masyarakatnya kurang perduli terhadap sampah. Dampak negatif yang ditimbulkan oleh masyarakat kota Medan dengan banyaknya sampah akan menjadi lebih buruk untuk masyarakat kota Medan, dengan adanya iklan layanan masyarakat peduli sampah ini membuat masyarakat kota Medan menjadi peduli terhadap sampah yang ada disekitarnya, dan sampah tersebut tidak berdampak negatif seperti terjadinya sarang penyakit serta bau tidak sedap disekitaran kota Medan [2].

Dalam iklan peduli sampah ini membuat para masyarakat sadar dengan betapa pentingnya untuk membersihkan sampah yang ada disekeliling mereka khususnya kota Medan, dan disekeliling kota Medan pun tidak terjadi banjir dimana-mana jika musim penghujan tiba, dengan adanya iklan layanan masyarakat ini pemerintahan kota Medan dapat mengarahkan seluruh masyarakat yang ada di kota Medan untuk lebih meningkatkan daya kesadarannya agar diciptakan lingkungkan yang bersih dan rapi.

\subsection{Media Komunikasi}

Media adalah alat atau sarana yang diaplikasikan untuk menyampaikan pesan dari komunikator kepada target audience. Ada beberapa teori yang memandang bahwa dalam komunikasi antar manusia, maka media yang paling dominasi dalam berkomunikasi adalah panca indera manusia seperti mata dan telinga. Pesan-pesan yang diterima oleh panca indera selanjutnya diproses oleh pikiran manusia untuk mengontrol dan menentukan sikapnya terhadap sesuatu yang di sampaikan, sebelum dinyatakan dalam tindakan serta dalam media komunikasi tersebut masyarakat lebih peka dengan adanya tampilan media tersebut. [1]

Dapat disimpulkan pengertian media komunikasi adalah suatu alat bantu yang digunakan untuk mempermudah masyarakat dalam menyampaikan informasi dari 
seseorang kepada orang lain dengan maksud dan tujuan tertentu dengan fungsi mempermudah penyampaian pesan sehingga dapat memperjelas maksud dan tujuan penyampaian pesan, mengefektifkan penyampaian pesan dan sebagai alat untuk membangkitkan motivasi dalam mendengarkan suatu informasi serta agar masyarakat lebih memahami maksud dan tujuan tersebut.

\subsection{Media Komunikasi Visual yang dipilih dalam membuat ILM}

Untuk memberikan pesan kepada target audience dan agar tujuan dapat dijalankan sesuai dengan yang telah ditentukan, maka penulis memilih beberapa jenis media-media komunikasi alternatif yang dapat dijangkau oleh seluruh target audience dengan maksud untuk menumbuhkan kepedulian dan kesadaran masyarakat yang ada di Kota Medan, yaitu :

\subsubsection{Poster}

Poster : merupakan media grafis yang memuat unsur teks dan gambar atau ilustrasi yang dipasang atau ditempel pada dinding. Visualisasi dalam iklan layanan masyarakat setiap unsurnya adalah rinci, jelas, realistis, sederhana dan singkat dengan warna yang mencolok sesuai misinya [1].

Jadi poster adalah sarana kampanye yang penempatannya dengan ditempel pada dinding atau tempat- tempat strategis lainnya agar untuk menarik perhatian target audience agar menerima pesan yang disampaikan. Poster sebagai media luar ruangan, memiliki kualitas yang berbeda dengan iklan lain, dapat berfungsi sebagai iklan mengingatkan dan mendukung kampanye iklan di media lain seperti media cetak:

Kekuatan poster dalam iklan layanan masyarakat :

a) Memiliki frekuensi tinggi.

b) Biaya relatif rendah dengan jangkauan cukup luas.

c) Lebih mudah dimengerti (bahasa gambar) tidak banyak teks.

d) Dapat membuat target audience mengingat isi poster bila bentuk menarik dan peletakan strategis.

e) Kualitas kertas bagus, sehingga dapat menampilkan visualisasi yang baik.

\subsubsection{Brosur}

Brosur yang bersifat informatif, membuat penyampaian pesan melalui media brosur sangat efektif pesan yang disampaikan dapat lengkap dan detail.

Kekuatan brosur:

a) Bersifat informatif.

b) Mudah dibawa dan disimpan.

\subsubsection{X-Banner}

X-Banner adalah media komunikasi grafis yang dibuat dari kertas atau dengan bahan lain dan dipasang dengan direntangkan dengan plastik atau logam yang berbentuk X sebagai penyangga serta dapat berdiri sendiri.

X-Banner merupakan media promosi yang mempunyai cara direntangkan ketempat yang lebih terarah sehingga dapat berdiri dengan stabil dengan permukaan rata. Banner adalah media promosi yang berbentuk seperti poster dengan bantuan alat 
untuk memberdirikan banner tersebut, media ini ukurannya cukup beragam ada yang $60 \times 160 \mathrm{~cm}, 90 \times 160 \mathrm{~cm}$.

Kekuatan banner

a) Kualitas dari banner tersebut cetaknya bagus sehingga mudah menarik perhatian audience.

b) Ukuran yang cukup besar sehingga memudahkan untuk menyampaikan pesan yang baik kepada masyarakat kota Medan.

\subsubsection{Stiker}

Stiker merupakan media komunikasi grafis tentang produk, jasa ataupun identitas yang dapat ditempel pada berbagai tempat, umumnya berbahan kertas vinyl yang mengandung perekat yang berfungsi untuk menarik perhatian masyarakat kota Medan.

Stiker merupakan salah satu bentuk pajangan yang lama, yang masa bertahannya lama. Bentuk berupa potongan-potongan kertas yang bisa ditempelkan di sudut-sudut atau jendela serta stiker tersebut bertujuan untuk meningkatkan daya ketertarikat masyarakat dengan ILM tersebut.

Kekuatan stiker:

a) Mudah disebarkan dan sampai pada target audience.

b) Dapat diselipkan pada media yang lain sehingga mempermudah penyebaran pada stiker tersebut.

c) Masyrakat merasa senang dengan mendapat stiker, karena dapat dipakai untuk menghias suatu tempat atau benda lain.

d) Stiker yang ditempelkan pada suatu benda atau tempat dapat dilihat oleh banyak masyarakat.

\subsubsection{Kalender}

Sebuah sistem yang bertujuan untuk memberi nama pada sebuah periode waktu. Nama- nama ini dikenal sebagai tanggal kalender. Tanggal ini bisa didasarkan dari gerakan-gerakan benda angkasa seperti matahari dan bulan. Kalender juga dapat mengacu kepada alat yang mengilustrasikan sistem tersebut sehingga kalender tersebut dapat menbantu daya tarik target audience untuk perduli terhadap sampah [1].

\section{STUDI LITERATUR}

\section{II.1. Teori Psikologi Persepsi}

Aplikasi teori persepsi itu sangat luas, persepsi bisa dikaitkan dengan sikap hidup manusia, kelompok masyarakat atau golongan tertentu, dn umumnya dikaitkan pula dengan suku atau agama dan sebagainya. Dalam hal ini teori persepsi lebih dikaitkan dengan pekerjaan desainer grafis yang bertujuan untuk menciptakan media pesan komunikasi.Beberapa contoh yang dimaksud adalah berbagai tanda dan pean visual yang ditemukan pada gambar, poster, iklan, seni visual, produk, dan lingkungan. (Pujiyanto, 2014)

Teori ini dapat diaplikasikan kepada unit desain visual sederhana seperti gambar, poster, lukisan, atau bidang kerja desain yang terbatas. Hal ini dapat dibandingkan dengan dengan infomasi visual yang lebih kompleks, yaitu desain media visual yang ditujukan 
kepada pengamat tertentu, seperti pada produk buku, majalah, surat kabar, animasi, film, dan sebagainya.

\section{PEMBAHASAN}

Salah satu faktor yang menyebabkan rusaknya lingkungan hidup yang sampai saat ini masih tetap menjadi masalah besar bagi bangsa Indonesia khususnya di kota medan adalah pembuangan sampah masyarakat kota medan sudah banyak yang sering membuang sampah sembarangan dan di biarkan begitu saja tanpa di apa-apakan .Hal tersebut tentunya sangat berpengaruh terhadap lingkungan sekitar di mana lingkungan menjadi kotor dan sampah yang membusuk akan menjadi bibit penyakit di kemudian hari.

Sebaiknya sampah-sampah itu di bakar atau di kubur agar tidak tumbuh bibit-bibit penyakit yang menimpa masyarakat walaupun terbukti sampah itu dapat merugikan bila tidak di kelola dengan baik ,tetapi juga ada sisi manfaatnya hal ini di karenakan selain dapat mendatangkan bencana bagi masyarakat sampah juga dapat di ubah menjadi barang yang bermanfaat ,ke manfaat sampah ini tidak terlepas dari penggunaan dalam menangani dan juga kesadaran dan masyarakat untuk mengelolanya.

Metode penelitian yang digunakan dalam perancangan Iklan Layanan Masyarakat ini adalah metode penelitian kualitatif.Menurut Kiriyantono (2007), "riset kualitatif bertujuan untuk menjelaskan fenomena dengan sedalam-dalamnya melalui pengumpulan data sedalam-dalamnya" (p. 58).Menurut Bodgan \& Taylor (Moleong, 2006), mendefinisikan metodologi kualitatif sebagai "prosedur penelitian yang menghasilkan data deskriptif berupa kata-kata tertulis atau lisan dari orang-orang dan perilaku yang dapat diamati” (p. 4).

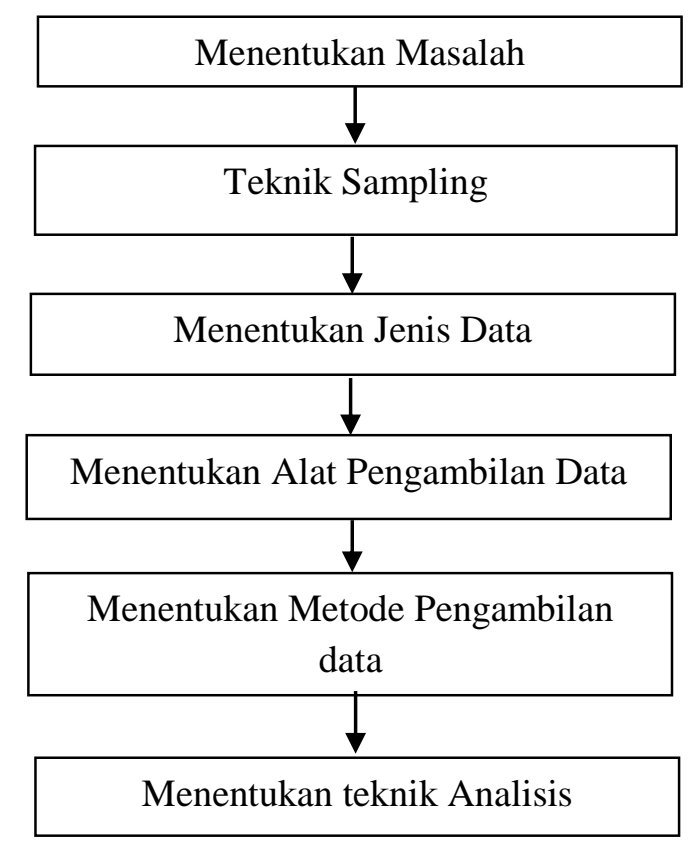

Gambar 1. Model Desain Riset Kualitatif

Dalam penelitian ini, perancang menggunakan teknik sampling secara acak.Dimana mengambil beberapa narasumber sebagai sumber data dalam penelitian ini. Pemilihan narasumber ini didasarkan pada kriteria yang penulis tentukan, seperti dari kelompok pelajar dan ibu rumah tangga yang ada di kota Medan. 


\section{III.I. Desain Komunikasi Visual}

Desain berasal dari bahasa latin yaitu designare, atau dari bahasa inggris design yang berarti menggambar, merancang. Desain sama halnya dengan merancang. Merancang adalah proses penciptaan rupa untuk maksud tertentu . (Wong, 1986:1) [1].

Istilah komunikasi atau dalam bahasa Inggris communications berasal dari kata Latin communication, dan sumber dari kata communis yang berarti sama, sama di sini maksudnya adalah sama makna. Jadi kalau target audience terlibat dalam komunikasi, misalnya dalam bentuk percakapan maka komunikasi akan terjadi atau berlangsung selama ada kesamaan makna mengenai apa yang dipercakapkan dalam hal terkait ilkan layanan masyarakat peduli sampah.

Pengertian visual adalah segala sesuatu yang dapat dilihat dan dapat dipakai untuk menyampaikan arti, makna, atau pesan dan direspon oleh indera penglihatan atau suatu bahasa yang tertangkap oleh panca indera terutama mata, di mana kita bisa menafsirkan dari apa yang telah kita lihat dan kemudian kita mencernanya dan mengetahui tentang iklan layanan masyarakat.

Komunikasi ini mempergunakan mata sebagai alat penglihatan. Komunikasi visual adalah komunikasi yang menggunakan bahasa visual, di mana unsur dasar bahasa visual (yang menjadi kekuatan utama dalampenyampaian pesan) adalah segala sesuatu yang dapat dilihat dan dapat dipakai untuk menyampaikan arti, makna, atau pesan (Kusrianto, 2007:10) [1].

Desain Komunikasi Visual adalah suatu disiplin ilmu yang bertujuan untuk mempelajari konsep-konsep komunikasi serta ungkapan kreatif melalui berbagai media untuk menyampaikan pesan dan gagasan secara visual dengan mengelola elemenelemen grafis yang berupa bentuk dan gambar, tatanan huruf, serta komunikasi warna serta layout (tata letak atau perwajahan) dengan demikian, gagasan bisa diterima oleh orang atau kelompok yang menjadi sasaran penerima pesan (Kusrianto, 2007:2). Desain Komunikasi Visual adalah sebagai aplikasi penerapan dari keterampilan seni dan komunikasi untuk kebutuhan bisnis dan industry serta untuk meningkatkan daya kepekaan terhadap audience [1].

Aplikasi ini dapat meliputi periklanan dan produk, menciptakan identitas visual untuk institusi, produk, dan perusahaan dan lingkungan grafis. Dan sebagai pesan informasi secara visual menyempurnakan pesan dalam publikasi. Media komunikasi massa cetak, film, dan elektronik adalah sarana untuk pesan visual (Suyanto, 2004: 8) [1].

Menurut Bogusky (2009:23) Desain Komunikasi Visual adalah suatu ilmu terapan seni rupa, komunikasinya merupakan simbol yang menggunakan tanda-tanda dan memiliki makna dari sebuah konsep yang ditampilkan dalam sebuah media visual. Komunikasi visual menitik beratkan pada hal perencanaan yang mengembangkan bentuk lambang, gambaran-gambaran yang dapat kita lihat lewat indera penglihatan sebagai bahasa pesan atas informasinya dan dapat mempengaruhi individu yang berkomunikasi. DesainKomunikasi Visual mempelajari konsep komunikasi dan ungkapan kreatif, teknik dan media, elemen desain grafis berupa bentuk gambar, huruf dan warna, serta tata letaknya, sehingga pesan dan gagasan dapat diterima oleh target audience [1]. 
Berdasarkan uraian di atas ketika dijabarkan kembali dapat disimpulkan bahwa Desain Komunikasi Visual adalah suatu disiplin ilmu yang bertujuan untuk mempelajari konsep-konsep komunikasi serta ungkapan kreatif audience melalui berbagai media untuk menyampaikan pesan dan gagasan secara visual kepada target audience dengan cara mengelola elemen-elemen grafis yang berupa bentuk dan gambar, tatanan huruf serta komposisi warna serta dengan demikian gagasan akan dapat diterima oleh orang atau kelompok yang menjadi sasaran penerima pesan serta membuat daya tarik terhadap target audience untuk penyampaian pesan yang terdapat di iklan layanan masyarakat tersebut.

Untuk Iklan Layanan Masyarakat Peduli Sampah, media utama yang akan digunakan sebagai iklan adalah spanduk. Media ini dirasa sangat efektif untuk menyampaikan pesan kepada target audience. Sedangkan untuk media pendukung, media publikasiakan dirancang berupa kaos.

Berikut adalah perincian tentang media yang akan dipergunakan dalam IklanLayananMasyarakat Peduli Sampah :

\section{Media Utama}

Media utama yang akan digunakan adalah Spanduk, Spanduk adalah mediapromosi berupa media cetak. Dari segi ukuran, Spanduk jauh lebih kecil bila dibandingkan dengan baliho.Poster biasanya ditempatkan di ruang publik yang memungkinkan untuk diperhatikan dalam waktu yang cukup lama, seperti di dalam ruangan sebuah gedung dan pada ruang publik lainnya.

Beberapa keunggulan dari media ini antara lain :

- Karena sifatnya yang fleksibel, maka poster memungkinkan untuk ditempel di berbagai ruang publik.

- Kemampuan reproduksinya cukup tinggi.

- Informasi yang ada di dalam poster bisanya lebih akurat dan rinci, sehingga masyarakat dapat menangkap informasi dengan lebih jelas.

- Menarik perhatian, karena poster memungkinkan penciptaan dan eksplorasi desain grafis yang sangat luas.

2. Media Pendukung

Selain media utama, dalam perancangan iklan layanan masyarakat juga di ikut sertakan media pendukung, tujuannya adalah sebagai sarana untuk mendukung media utama dalam mempromosikan kampanye sosial ini di kota Medan. Di antaranya adalah : kaos, selain dari itu dengan adanya media pendukung akan bermanfaat untuk mendukung terciptanya kampanye ini dan juga menjangkau langsung audience yang dituju. Serta media pendukung ini berguna untuk meningkatkan keyakinan masyarakat untuk perduli terhadap sampah masyarakat. 
III. III.II. DesainIklan Layanan Masyarakat

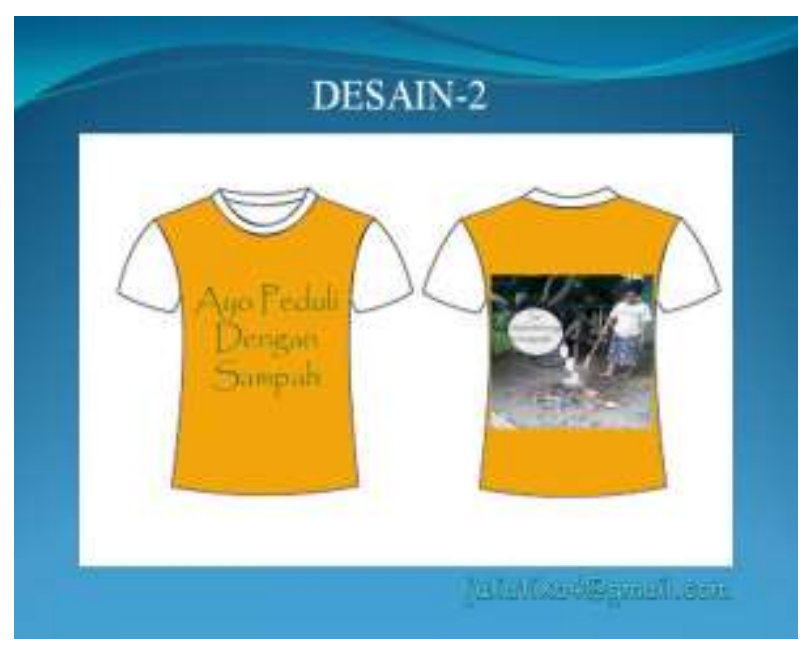

\section{Gambar 2. Desain T-shirt Iklnn Layanan Masyarakat Peduli Sampah}

Sumber : Juli Atika, Studio II ILM, 2017

Gambar diatas menunjukan salah satu dari media pendukung Iklan Layanan Masyarakat Peduli Sampah. Melalui gambar tersebut yang dirancang oleh peneliti dapat dipahami oleh masyarakat kota Medan untuk peduli tentang sampah halini dikarenakan pemaknaan tanda ataupun penanda pada desain komunikasi visual bisa dimaknai lebih dari makna sebenarnya tergantung dari orang yang melihat.

\section{III.III. Typograpy}

Beberapa kalimat yang akan masukkan untuk menjadi pelengkap desain adalah sebagai berikut:

- Janganbiarkan kami menumpukdansayangi kami

- Tolonghargai kami danjanganbiarkan kami berserak

- Terimakasihtelahmencintaidanmenyayangiku

- Malu dong buangsampahsembarangan

- Buanglahsampahpadatempatnya

Dari beberapa kalimat yang ada di atas, maka yang terpilih sebagai IklanLayananMasyarakat adalah "JANGAN BIARKAN KAMI MENUMPUK DAN SAYANGI KAMI", "TOLONG HARGAI KAMI DAN JANGAN BIARKAN KAMI BERSERAK”, "TERIMA KASIH TELAH MENCINTAI DAN MENYAYANGIKU”.

Dari kalimat yang sudah di pilih tersebut kemudian dicari alternatif jenis huruf yang yang cocok untuk di aplikasikan ke desain yang akan kita buat nantinya yaitu sebagai berikut: 
Tabel 1 : Typograpy

\begin{tabular}{|l|c|c|}
\hline \multicolumn{1}{|c|}{ HEADLINE } & JENIS HURUF & STATUS \\
\hline $\begin{array}{l}\text { TERIMA KASIH TELAH } \\
\text { MENCINTAI DAN } \\
\text { MENYAYANGIKU }\end{array}$ & Arial & $\mathrm{X}$ \\
\hline $\begin{array}{l}\text { TERIMA KASIH TELAH } \\
\text { MENCINTAI DAN } \\
\text { MENYAYANGIKU }\end{array}$ & Cooper Black & $\mathrm{X}$ \\
\hline $\begin{array}{l}\text { TERIMA KASIH TELAH } \\
\text { MENCINTAI DAN } \\
\text { MENYAYANGIKU }\end{array}$ & papyrus & $\checkmark$ \\
\hline
\end{tabular}

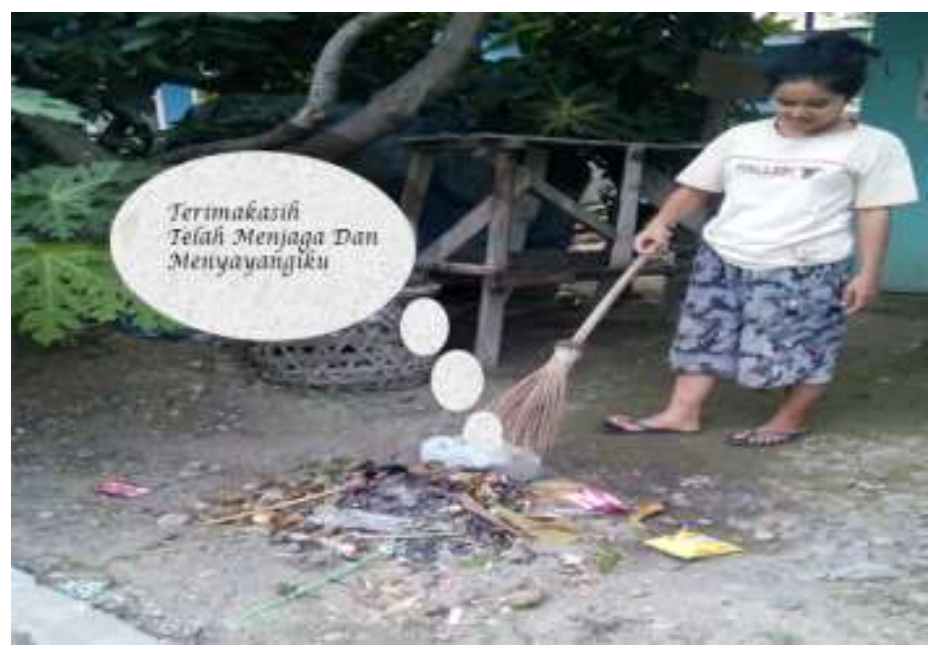

Gambar 3 : Media PosterPeduli Sampah

\section{KESIMPULAN}

Sumber : Juli Atika, Studio II ILM, 2017

Lingkungan merupakan sebuah aspek penting di dalam kehidupan manusia yang harus terus dijaga oleh siapapun. Di era yang sudah modern ini masih saja ada pihak yang kurang memperhatikan kondisi lingkungan yang ada, mereka tidak memedulikan kondisi lingkungan yang buruk. Kesadaran adalah hal yang dibutuhkan saat ini, untuk peduli dan menjaga lingkungan hidup yang ada. Kesadaran ini sebaiknya diberikan terutama pada generasi muda yang kelak akan meneruskan generasi yang ada. Oleh karena itu, penulis merancang pembuatan iklan masyarakat peduli sampah untuk wilayah kota Medan.

Adapun pembuatan iklan ini mengambarkan seseorang yang sedang melakukan pembersihan terhadap sampah yang ada dilingkungan sekitar rumahnya, sehingga kota Medan tersebut tidak sering mengalami kebanjiran pada saat turun hujan tiba, maka dari itu pembuatan iklan layanan masyarakat ini mendorong generasi kedepan untuk perduli trerhadap sampah dan memberikan kesan yang menarik terhadap lingkungan yang ada di kota Medan. 


\section{DAFTAR PUSTAKA}

[1] Pemanfaatan Limbah Rumah Tangga Universitas Indraprasta. 2014. JURNAL FORMATIF 4(2): 124-132

[2] Sarwono, Jonathan dan Hary Lubis. (2007). Metode Riset untuk Desain Komunikai Visual I. Yogyakarta : Penerbit Andi

[3] Pujiyanto.(2013). Iklan Layanan Masyarakat.Yogyakarta : Penerbit Andi

[4] Hakim, Zainal. (2012). Mengenal Istilah Warna. [Online]. Tersedia: http://www.zainalhakim.web.id/posting/mengenal-istilah-warna.html 10 Oktober 2013.

[5] Dinas Perhubungan Kota Medan

[6] Sumber: http://desainwebsemarang.weebly.com/blog/desain-komunikasi-visualdesain-grafis-dan-desain-umum

[7] http://repository.unpas.ac.id/12607/3/BAB\%20II.docx

[8] https://ejournal.bsi.ac.id/ejurnal/index.php/sketsa/article/download/270/228

[9] http://dir.unikom.ac.id/s1-final-project/fakultas-desain/desain-komunikasivisual/2010/jbptunikompp-gdl-ganeshyana-22810/6-unikom-g-i.pdf/pdf/6unikom-g-i.pdf 